Pobrane z czasopisma Annales L - Artes http://artes.annales.umcs.pl

Data: 26/04/2023 14:49:40

10.1515/umcsart-2015-0011

A N N A LES

UNIVERSITATIS MARIAE CURIE-SKŁODOWSKA

LUBLIN - POLONIA

VOL. XIII, 1

SECTIO L

2015

Instytut Sztuk Pięknych UMCS

MatgorZATA STĘPNiK

\title{
Obrazy Albionu. Pejzaże Paula Collinsona i Geda Quinna jako „teksty” o współczesnej kulturze
}

\begin{abstract}
Visions of Albion. The Landscapes by Paul Collinson and Ged Quinn as “Texts" about Contemporary Culture

Co to za miasto ponad pasmem gór

Trzaska zrasta się pęka w powietrzu fioletowym

Walace się wieże

Jerozolima Ateny Aleksandria

Wiedeń Londyn

Nierzeczywiste
\end{abstract}

Thomas Stearns Eliot ${ }^{1}$

\section{Nostalgia wyspy}

The Waste Land Thomasa Stearnsa Eliota, poemat wydany po raz pierwszy w 1922 roku, eksperymentatorski i prekursorski w formie - zważywszy choćby na rozwijaną wiele lat później przez Williama S. Burroughsa technikę cut-up ${ }^{2}-$ nade wszystko jednak profetyczny w warstwie znaczeniowej, stanowił inspirację

\footnotetext{
${ }^{1}$ T. S. Eliot, Jałowa ziemia, tłum. Cz. Miłosz, Kraków 1989, s. 31.

${ }^{2}$ William Seward Burroughs, jeden z „filarów” Beat Generation, począwszy od lat 60. ubiegłego wieku rozwijał technikę literackiej „wycinanki” bezpośrednio opierając się na niewiele wcześniejszych eksperymentach Briona Gysina (Minutes to go). Jakkolwiek tekst Eliota - podobnie
} 
dla jednego z najbardziej znanych płócien Ronalda B. Kitaja - If Not, Not (19751976) ${ }^{3}$. Charakterystyczna postać angielskiego poety ukazana została w lewej dolnej partii obrazu, dodajmy - dzieła znajdującego się obecnie w edynburskich zbiorach Scottish National Gallery of Modern Art. Górną część owej nieludzkiej, Jałowej ziemi wypełnia architektura aludująca wyraźnie do miejsca, którego Eliot nie mógłby wyimaginować sobie w najgorszych koszmarach - Auschwitz.

Kitaj, duchowy outsider i diasporyst ${ }^{4} \mathrm{z}$ wyboru, Amerykanin o żydowskich korzeniach zakochany w Anglii - do 1994 roku nawet z wzajemnością - należał, obok Luciana Freuda, Francisa Bacona, Franka Auerbacha czy Leona Kossoffa, do ścisłego „trzonu” The School of London. To właśnie zainicjowana przezeń w 1976 roku wystawa The Human Clay, goszcząca w przestrzeniach Hayward Gallery, wyznaczyła początek heroicznego etapu historii tejże prominentnej grupy. Pokaz ów, stanowiąc antytezę dla wszechpanującej jeszcze wówczas mody na malarstwo niefiguratywne, przypomniał to, co przez wieki stanowiło najwspanialszy aspekt angielskiej sztuki - element intelektualnie wyrafinowanej krytyki społecznej.

Znamienne, iż zaledwie rok po feralnej retrospektywie Kitaja w Tate Gallery, nad wyraz chłodno przyjętej przez krytykę, najbardziej prestiżową nagrodę artystyczną na Wyspach - Turner Prize odebrał Damien Hirst, kontrowersyjna „ikona” ruchu Young British Artists, autor - jakkolwiek w tym wypadku pojęcie autorstwa jest dyskusyjne - (niestety) licznych instalacji ze zwierzętami zanurzonymi w formaldehydowym roztworze ${ }^{5}$. Równie znamienne, że w roku 2011 Martin Boyce otrzymał tę samą nagrodę za ... śmietnik ${ }^{6}$.

jak aleatoryczne utwory Tristana Tzary i Marcela Duchampa - z pewnością również stanowił dlań źródło inspiracji.

${ }^{3}$ Szczególnie silne zabarwienie polityczne posiadają także dwa inne płótna Ronalda B. Kitaja: The Autumn of Central Paris. After Walter Benjamin (Jesień w centrum Paryża. Wedtug Waltera Benjamina) 1972-1973, ol. na pł., 152,4 x152,4 cm, obraz znajdujący się w nowojorskiej Kolekcji Susan Lloyd; oraz Cecil Court, London WC2 (The Refugees), 1983-1984, ol. na pł., w zbiorach Tate Gallery, (o ile tytuł odsyła nas do jednej z londyńskich dzielnic, podtytuł należy tłumaczyć jako: Uchodźcy).

${ }^{4}$ Artystom pozostającym w geograficznej i intelektualnej zarazem diasporze poświęcił Kitaj dwa manifesty w formie obszernych esejów: First Diasporist Manifesto (1989) oraz Second Diasporist Manifesto (2007).

${ }^{5}$ Bez wątpienia, do niezwykłej popularności twórców określanych dziś mianem Young British Artists przyczynił się bodaj największy potentat współczesnego rynku sztuki - Charles Saatchi, (w każdym razie - jeden z najbardziej prominentnych kolekcjonerów obok Larry'ego Gagosiana, czy Barbary Gladstone). Polemiczną odpowiedź na działalność artystów takich, jak Damien Hirst czy Tracey Emin, stanowi twórczość ruchu tzw. Stuckistów. Grupa ta ogłosiła swój manifest - The Stuckist Manifesto - w roku 1999.

${ }^{6}$ Ubiegłoroczny werdykt jury jest chyba najmniej kontrowersyjnym od lat. Nagrodę Turner Prize 2014 zdobył Duncan Campbell (ur. 1972) za udział w pawilonie szkockim podczas ostatniego Biennale w Wenecji. 
Główny przedmiot podejmowanych przeze mnie analiz stanowić będą twórcze imaginaria współczesnych pejzażystów - Paula Collinsona i Geda Quinna, artystów pozostających poniekąd poza mainstreamem brytyjskiej sztuki (choćby tej spod znaku YBA). Zarówno hiperrealistyczne płótna Collinsona, odwzorowujące ,mikrokosmosy” misternie skonstruowanych diaporam, jak i czule wycyzelowane w laserunkowej technice obrazy Quinna - zawierające subtelne cytaty z Jacoba Ruisdaela, Claude'a Lorraina, Caspara Davida Friedricha czy Philipa Otto Rungego - są czymś znacznie więcej niż wyrazem twórczego eskapizmu w domenę pięknej formy.

Sądzę, iż można je interpretować jako swoiste traktaty o kulturze, polityczne „teksty”, a może wręcz manifesty zamknięte w dwuwymiarze podobrazia. Wolno nam dostrzec w nich wyraz silnego Kulturpessimismus, refleks coraz bardziej skondensowanej w naszej kulturze mieszanki rozczarowania i strachu. Obrazy Collinsona i Quinna są wizjami martwej, a przynajmniej - chylącej się ku upadkowi cywilizacji Okcydentu; co dawno już wszakże zmitologizował Oswald Spengler (Zmierzch Zachodu, wyd. oryg. Der Untergang des Abendlandes, 1918-1922)7, a do czego dziś znów chętnie, niejako z impetem wtórnej fali wracają socjologowie i ekonomiści, na przykład jakże popularny Jacques Attali ( $Z a-$ chód. 10 lat przed totalnym bankructwem, wyd. oryg. Tous ruinés dans dix ans) ${ }^{8}$.

Malarskie światy obydwu artystów stanowią jednocześnie doskonałą ilustrację pojęcia the englishness, owej specyficznej kategorii analizowanej onegdaj przez Nikolausa Pevsnera (The Englishness of English Art, 1956), a bliżej naszym czasom - przez Sir Roya Stronga (The Spirit of Britain. A Narrative History of the Arts, 2000) oraz Petera Ackroyda, którego inspirującej książce z 2002 roku, oparzonej tytułem Albion. The Origins of the English Imagination zamierzam poświęcić teraz osobną uwagę.

\footnotetext{
${ }^{7}$ We Wprowadzeniu do swej książki Spengler stwierdza: „Musimy sobie uświadomić, że wieki XIX i XX - ów rzekomy szczyt liniowego wzrostu historii powszechnej - należy w rzeczywistości wykazać jako fazę starości w każdej dojrzałej do samych granic kulturze: ich znamionami są nie tyle socjaliści, impresjoniści, koleje elektryczne, torpedy, równania różniczkowe, bo te należą tylko do materii epoki, lecz ich cywilizacyjna duchowość również o całkiem innych możliwościach zewnętrznego kształtowania; że zatem teraźniejszość stanowi swoiste stadium przejściowe, które pojawia się niechybnie w pewnych warunkach; że istnieją zatem również dobrze określone stany późniejsze niż dzisiejsza sytuacja zachodnioeuropejska; że występowały one już niejednokrotnie w minionej historii i że tym samym przyszłość Zachodu nie jest nieograniczonym i nieskończonym parciem wzwyż i naprzód ku naszym aktualnym ideałom, lecz osobnym - ściśle ograniczonym i niechybnie określonym co do formy i okresu trwania - wydarzeniem historycznym o kilkusetletniej skali, które można (...) objąć wzrokiem, a ich istotne rysy wyliczyć”. O. Spengler, Zmierzch Zachodu, tłum. J. Marzęcki, Wyd. Aletheia, Warszawa 2014, s. 50. [podkr. M. S.]

${ }^{8}$ Zob. J. Attali, Zachód. 10 lat przed totalnym bankructwem, tłum. N. Mętrak, Warszawa 2010.
} 
Cóż zatem przesądzałoby o wyją̧tkowym charakterze angielskiej wyobraźni i wrażliwości? Co czyni tak pociągającą sztukę Albionu witającego przybyszy zgodnie z etymologicznym sensem tej nazwy - surową biela klifów, (celtyckie Albio, gaelickie Alba) ? Otóż, Ackroyd przyrównuje albiońską imaginację do wiecznie żywego strumienia albo też, w innym miejscu - do okręgu, pierścienia bez początku i końca; (The English imagination takes the form of a ring or circle. It is endless because it has no beginning and no end; it moves backwards as well as forwards).

W kontinuum gasnących i odradzających się form mieszczą się pewne stałe elementy, obecne także w oeuvres omawianych malarzy. Owe szczególne aspekty angielskiej wrażliwości, przenoszone w domenę sztuk wizualnych i literatury, proponuję na użytek niniejszych rozważań sprowadzić do następujących punktów:

\section{1) cienista melancholia}

Doskonałą ilustrację typowej dla Brytyjczyków skłonności do „kontemplowania pyłu" (contemplation of dust), jak wskazuje Ackroyd, stanowi już staroangielski termin dustsceawung ${ }^{10}$. Stan przenikliwego smutku ubranego w przeróżne odcienie szarości jest „wdzięcznym” tematem literackim, przedmiotem zarówno wnikliwych, introspekcyjnych analiz, jak i bardziej impresyjnych poetyckich obrazów, począwszy od Anatomii melancholii (The Anatomy of Melancholy) Roberta Burtona, wydanej po raz pierwszy w 1621 roku, poprzez Odę na melancholię (Ode on Melancholy) Johna Keatsa z roku 1819, aż po cytowany wyżej poemat Eliota. W przywoływanym kontekście postacią symboliczną, rzec by można - swoistym wzorem osobowym ,skłóconego z życiem” buntownika-samobójcy, staje się genialny mistyfikator Thomas Chatterton, który dokonuje żywota w 1770 roku, zażywszy dawkę arszeniku. Nuta melancholii zdaje się też od zawsze przenikać płótna angielskich pejzażystów, choćby samego Johna Constanble'a studiującego ciemne, złowieszcze chmury (Seascape Study with Raincluods, ok. 1824).

\section{2) silna wiara $w$ przeznaczenie}

Odzwierciedlona z kolei w staroangielskim pojęciu wyrd - przybiera ona nierzadko fatalistyczny wymiar. Częściej jednak idzie w parze ze spokojem pokładanym w to, co $i$ tak ma nastąpić. Jak stwierdza Ackroyd: „To prawdziwy obraz anglosaskiej mentalności, a przynajmniej echo tamtej [dawnej] świadomości, że kruchość istnienia i poczucie utraty są nieodłączną częścią ludzkiej kondycji;

\footnotetext{
${ }^{9}$ P. Ackroyd, Albion. The Origins of the English Imagination, London 2002, s. XIX.

${ }^{10}$ Ibid., s. 54.
} 
w świecie tym żywot był niepewny a pierwotną boskość stanowił los, przeznaczenie lub »wyrd «". ${ }^{11}$

\section{3) atmosfera nostalgii}

Niejako organicznie przenika ona albiońskie malarstwo i literaturę; tak mocno, iż zdawać by się mogło, że „Anglicy rodzą się już patrząc wstecz”, (... as if the English were born looking backwards ${ }^{12}$. Paul Collinson w prywatnej korespondencji polecił mi interesującą rozprawę autorstwa Svetlany Boym - The Future of Nostalgia (Basic Books, 2001). Pisząca na szczęście „niemodne” rzeczy wyrafinowana intelektualistka i multimedialna artystka analizuje w swoich tekstach na przykład zamieszczonym w Sieci Off-Modern Manifesto - tematykę niekiedy wdzięcznej, innym razem zaś karkołomnej fuzji tradycji i novum. To, jak pisze Collinson, iście „,angielski paradoks”, przejawiający się choćby w architekturze mieszkalnej: „Niczego nie lubimy bardziej, niż życia w przeszłości ze wszystkimi nowoczesnymi udogodnieniami". (We like nothing more than living in the past with all modern conveniences) ${ }^{13}$.

Co istotne, te formy albiońskiej sztuki, które odzwierciedlają mentalny klimat nostalgii, pozostając przy tym uroczo niemodnymi, w sposób paradoksalny, niosą zwykle rewolucyjny potencjał. Znakomity przykład w tej materii stanowi, jak sądzę, zapatrzona w heroiczną przeszłość, a jednocześnie niezwykle, jak na swój czas, ,wywrotowa” sztuka Prerafaelitów.

\section{4) swoista „bezcielesność”}

Zaobserwowana onegdaj przez Pevsnera, we wspomnianym dziele The Englishness of English Art, właściwa Anglikom strategia omijania tematu ciała silnie kontrastuje z kontynentalną, bujną zmysłowością, zwłaszcza synestetyczną wręcz „mięsnością" unaocznioną na płótnach dawnych mistrzów italskich czy hiszpańskich. (Wyjątek w obszarze współczesnej sztuki brytyjskiej stanowią werystyczne akty Luciena Freuda. Nawet bowiem u Francisa Bacona ciało jest poniekąd zdegradowane i zdematerializowane). Charakterystyczne, że domeną pewnego rodzaju zmysłowości w ikonografii angielskiego malarstwa pozostaje pejzaż. W angielskiej sztuce, uwolnionej od imperatywu voluptas carnis, ,bez-

\section{${ }^{11}$ Ibidem.}

„It is a true image of the Anglo-Saxon mind, or at least an echo of that consciousness which considered transience and loss to be part of the human estate; it was a world in which life was uncertain and the principal deity was fate or destiny or »wyrd«". [ thum. M.S.]

${ }^{12}$ Ibid., s. 62.

${ }^{13} \mathrm{Z}$ prywatnej korespondencji. Cytat zamieszczony dzięki uprzejmości Artysty. 
cielesność" idzie często w parze z zamiłowaniem do detalu, do form linearnych i zminiaturyzowanych.

\section{5) uwielbienie dla miniatury}

Predylekcje do miniaturowych form, do konstruowania artystycznych mikrokosmosów, ujawniają się w sztuce angielskiej od wielu wieków, być może od jej prapoczątków. Dość wspomnieć w tym wypadku o Braciach Winchesterskich, niezwykle finezyjnych XI-wiecznych iluminatorach, czy też o tradycji XVI-wiecznego miniaturowego portretu, w jakim niepodważalne mistrzostwo osiągnął Nicholas Hilliard, między innymi autor konterfektów królowej Elżbiety I. Ów kult miniatury manifestuje się także w przepięknych słowach Williama Blake’a, pochodzących z Wróżb niewinności (Auguries of Innocence):

Zobaczyć świat w ziarenku piasku,

Niebiosa w jednym kwiecie $\mathrm{z}$ lasu.

W ściśniętej dłoni zamknąć bezmiar,

$\mathrm{W}$ godzinie - nieskończoność czasu ${ }^{14}$.

Ackroyd wyraża tezę, iż angielskie przywiązanie do miniatury, „znajdowanie przyjemności w rzeczach małych" może po prostu wynikać z warunków życia na „małej wyspie” 15 . Co interesujące, rys przedziwnego „pragnienia miniaturyzowania obsesji" dostrzega też uczony we współczesnych brytyjskich powieściach kryminalnych, w których wszelkie niegodziwości i zbrodnie popełniane są nie w metropoliach, lecz w małych, sennych miasteczkach ${ }^{16}$.

\section{6) miłość do ruin, szczątków i reliktów}

Symboliczna dla tegoż - jak powiada Ackroyd - , przedziwnego angielskiego romansu ze śmiercią" (,,curious English love affair with death”) ${ }^{17}$, jest postać

${ }^{14}$ Wiersz w przekładzie Zygmunta Kubiaka. Źródło internetowe: http://poema.pl/publikacja/22217-wyrocznie-niewinnosci [dostęp: 07.03.15].

$\mathrm{W}$ oryginale, fragment ów brzmi następująco:

„To see a World in a Grain of Sand

And a Heaven in a Wild Flower

Hold Infinity in the palm of your hand

And Eternity in an hour".

W. Blake, Auguries of Innocence, [w:] G. Keynes (red.), Poetry and Prose of William Blake, London 1932, s. 118.

${ }^{15}$ Ackroyd, op. cit., s. 274.

${ }^{16}$ Zob. Ibid., s. 274-275.

${ }^{17}$ Ibid., s. 242. 
Byrona spijającego wino z mnisiej czaszki w ruinach rodzinnej posiadłości Newstead Abbey lub równie dobrze - postać Percy Shelleya spisującego Prometeusza rozpętanego (Prometheus Unbound) wśród ruin Term Karakalli. Fascynacja reminiscencjami przeszłości idzie niekiedy w parze z celową archaizacją, a wręcz antykizacją języka literackiego, czego przykład stanowią dzieła Johna Miltona. Także i teraz Albion zdaje się tęsknić za ,utraconym rajem” dawnej świetności.

\section{Antyczne zgliszcza i ,fantazja mikroskopu”}

Z tajemnymi, malarskimi uniwersami Paula Collinsona i Geda Quinna, znanymi mi wcześniej jedynie $\mathrm{z}$ reprodukcji, zetknęłam się kilka lat temu podczas podróży do Liverpoolu, będącego wszakże nie tylko kolebką Beatlesów, ale też siedzibą jednego z oddziałów Tate Gallery. Co znamienne w kontekście niniejszych rozważań, edycja Liverpool Biennial 2012, organizowanego, jak zawsze zresztą, pod auspicjami Tate, opatrzona została tytułem The Unexpected Guest ${ }^{18}$. Peregrynując do innej, równie szacownej liverpoolskiej instytucji - Walker Art Gallery, liczyłam na estetyczną, niebiańsko smaczną ucztę, jakiej dostarcza „kanoniczne" brytyjskie malarstwo, zwłaszcza tamtejsze przepiękne zbiory Prerafaelitów. (Rzecz jasna, nie zawiodłam się). W tym czasie, w przestrzeni Walker Art Gallery można było również oglądać prace ścisłego grona uczestników John Moores Painting Prize - bodaj najbardziej prestiżowego konkursu malarskiego na Wyspach Brytyjskich, organizowanego od 1957 roku $^{19}$. Znalazło się na owej wystawie sporych rozmiarów płótno Collinsona, zatytułowane Temple of Ancient Virtue (drugi z funkcjonujących tytułów to Pegasus Snack Bar) oraz namalowana $\mathrm{z}$ epickim rozmachem kompozycja The Exiled Forever Coming in to Land autorstwa Quinna (obydwa obrazy z 2010 roku). W ubiegłym roku natomiast, Collinson zaprezentował intrygujący obraz zatytułowany Et in Arcadia lego, do którego pozwolę sobie jeszcze powrócić w stosownym miejscu. (Dodam jedynie, że zwy-

${ }^{18}$ Ostatnia edycja, zamknięta 26 października 2014, nosiła tytuł: A Needle Walks into a Haystack.

Oto adres oficjalnej strony Liverpool Biennial: http://www.biennial.com/

${ }^{19}$ Pierwsza edycja konkursu, zainicjowanego przez biznesmena i filantropa Johna Mooresa, miała miejsce w roku 1957. Główną nagrodę otrzymał wówczas Jack Smith (za obraz Creation i Crucifixion). Dekadę później Grand Prix zdobył David Hockney (za „kanoniczne” dziś płótno Peter Getting Out of Nick's Pool). Honorowym patronem John Moores Painting Prize jest ,ikona” brytyjskiego pop-artu - Sir Peter Blake.

Oto adres oficjalnej strony konkursu: http://www.liverpoolmuseums.org.uk/walker/johnmoores/ 
ciężczynią edycji JMPP 2014 została Rose Wylie, malarka urodzona w Kencie w roku 1934. Nagrodzony obraz nosi tytuł PVC Windows and Floorboards).

Warto przy okazji nadmienić, że Walker Art Gallery stała się medialną „bohaterką" w 2011 roku, kiedy to Banksy, najbardziej znany pośród anonimowych artystów, umieścił w jednej z sal popiersie kardynała-gorszyciela, jednocześnie, wizualną metaforę dla jednego z „grzechów głównych” - Cardinal Sin.

Paul Collinson urodził się w 1959 roku w Kingston upon Hull, przemysłowym mieście w północno-wschodniej Anglii. Jest absolwentem sztuk pięknych na tamtejszej Humberside Polytechnic, jak powiada - „samozatrudniającym się artystą", parającym się niekiedy również pracą kuratorską. Jego twórczy modus operandi polega na konstruowaniu miniaturowych światów w postaci dioram - co też może przywodzić na myśl pracę modelarza - następnie, fotografowaniu owych niepokojących mikrokosmosów, a w decydującej części - najmożliwiej starannym przenoszeniu wizji zapisanych okiem aparatu „klasyczną” techniką olejną na płótno.

Widzimy oto w przedziwnych konstruktach angielskiego malarza dwa przemieszane porządki: ruiny i odpryski onegdaj dumnej, grecko-rzymskiej kultury oraz „,naleciałości” czegoś obcego, jakiegoś nieokiełznanego żywiołu. W rekwizytorium przezeń wykorzystywanym odnaleźć można postaci ludzkie - liche, ledwo zauważalne lalki, pozbawione znamion indywidualności, a także figurki mitycznych zwierząt: pegaza - symbolu natchnienia i byka, w którego postać, jak pamiętamy przecież, wcielił się Zeus, by uwieść Europę. Tu jednak boskie stworzenia przybierają formę tandetnych, plastikowych zabawek. Upokorzony Pegaz staje się reklamą przydrożnego baru z fast foodem, usadowionego na ruinach Światyni antycznej cnoty (Temple of Ancient Virtue, 2010).

Warto zaznaczyć, iż architektoniczne nazwy pojawiające się tytułach niektórych obrazów nawiązują nie tylko do odległej kultury antyku, ale też, w sposób bardziej bezpośredni, do urokliwego XVIII-wiecznego kompleksu Stowe Gardens w Buckinghamshire. Tam właśnie znajduje się wybudowana przez Williama Kenta w roku 1734 perystylowa rotunda - Temple of Ancient Virtue, o formie inspirowanej po części Świątynią Westy w Tivoli.

U Collinsona, w „świątyniach” i „relikwiarzach” brytyjskiego, rzec można - postkolonialnego dziedzictwa, brzydkie i trywialne graffiti mąci spokój albiońskiego, bladego nieba (Heritage Lottery z 2007 roku, The Shrine of British Worthies, 2009). Delikatnemu rysunkowi korynckiej kolumny towarzyszą bezkształtne litery nasprejowane na betonowych ścianach (Temple of Liberty, 2010). Na płótnie zatytułowanym Civic Trust (2010) obraz człowieka witruwiańskiego koegzystuje w cichej desperacji z plakatami głoszącymi przewrotną pochwałę zakupów (confessions of a shopaholic) i z bezładną, niewyzutą z ortograficznych błędów, wulgarną bazgraniną (save yorself, dog shit). 
Szczątki rozbitych maszyn - często występujący motyw - porasta gęsty, dziki bluszcz (Wilderness, 2010). Wszędzie niemal natykamy się na wraki samochodów, nawet spacerując po Elizejskich Polach (The Elysian Fields, 2006). „Poszukując malowniczości" znajdujemy skorodowane maszyny i roztrzaskane furtki (In Search of the Picturesque, 2009). Czyżby furtki strzegące kiedyś „,naszego” bezpiecznego świata? Chyba tak, skoro jeden z obrazów opatrzono krzyczącym tytułem Get off my Land! (2004). Lecz kto ma stąd zniknąć? I kto jest tu gospodarzem? Kiedy przyjazny gość (hospes) zamienia się w podejrzanego, we wroga (hospis) ? ${ }^{20}$ A może ów obcy (ksenos) jest immanentnie wpisany w społeczną strukturę, jest jej po prostu niezbędny? ${ }^{21}$

Sądzę, iż warto poświęcić jeszcze osobną uwagę warstwie semantycznej najnowszych prac artysty, układających się naturalnie - jak sam zresztą przyznaje - w znaczeniowo koherentny, a niezamierzony wcześniej cykl. Mam na myśli zwłaszcza trzy obrazy, a mianowicie: Sculpture Park (2012), wspomniany już olej opatrzony przewrotnym tytułem Et in Arcadia lego (2013) oraz Cold Pastoral (2014).

Inspiracją do powstania pierwszego z wymienionych płócien była lektura eseju Roberta Smithsona, poświęconego w sposób bezpośredni estetyce Central Parku (zaprojektowanego przez Fredericka Olmsteda i Calverta Vaux) w pośredni zaś - kategorii malowniczości (picturesque), zapożyczonej przez „ojca” amerykańskiej architektury pejzażu od Williama Gilpina i Uvedale'a Price'a ${ }^{22}$. W rzeczonym tekście zatytułowanym Frederick Law Olmsted and the Dialectical Landscape, wydanym po raz pierwszy w 1973 roku, Smithson wskazuje na - niejako organicznie wynikającą z XVIII-wiecznej koncepcji picturesque - dialektykę pejzażu, w której tezę stanowi gładkość, delikatność i wysublimowanie natury

${ }^{20}$ Do etymologicznego znaczenia słów hospes i hostis odniósł się prof. Cezary Wodziński podczas drugiego wykładu z cyklu Zagadka gościnności. Nasza Odyseia, wygłoszonego w lubelskim Trybunale Koronnym, (dn. 30.11.12 r.).

${ }^{21} \mathrm{~W}$ tym kontekście interesująco brzmią słowa Terry’ego Eagletona, kontrowersyjnego brytyjskiego teoretyka kultury: „O ile pojawienie się nauki ścisłej znanej jako antropologia wyznacza moment, w którym Zachód podjął się przekształcenia innych społeczeństw w prawowite obiekty badań, o tyle prawdziwym przejawem kryzysu politycznego jest moment, w którym sam Zachód poddaje się takiemu przekształceniu. W jego społeczeństwach także bowiem można znaleźć dzikusów - tajemnicze, posługujące się na wpół zrozumiałą mową istoty podległe nieokiełznanym pasjom i skłonne do buntowniczych zachowań. One także staną się obiektami badań określonych dyscyplin wiedzy”. T. Eagleton, Po co nam kultura?, tłum. Antoni Górny, Wydawnictwo MUZA, Warszawa 2012, s. 41-42 [podkr. M.S.].

${ }^{22}$ Zob. W. Gilpin, Observations Relative to Picturesque Beauty, (1789).

Zob. U. Price, Essay on the Picturesque, As Compared with the Sublime and The Beautiful, (1794). 
(the sublime), antyteze zaś przerażenie i poczucie wyobcowania, jakie budzi jej bezkres (vastness) ${ }^{23}$.

Subtelna aluzja do twórczości Smithsona zawarta jest również w jednym z najnowszych płócien Collinsona - Cold Pastoral. Otóż, jak wyznaje artysta, rozpadająca się, naprędce sklecona z brezentu i tektury szopa dla bezdomnych (czy też „,szałas”; ang. slangowe doss), kontrastująca w obrazie z surową czystością reklamy auta i wizerunku Kylie Minogue, jest estetycznym ukłonem w stronę Partially Buried Woodshed, instalacji zrealizowanej przez Smithsona w 1970 roku w Ohio ${ }^{24}$. Społeczne kontrasty i kontradykcje, do których nawiązuje płótno, spięte zostały swoistą klamrą w postaci napisu - tu brzmiącego nieledwie ironicznie - Omnes Cives, a zatem - „Wszyscy są obywatelami”. Co jednak najistotniejsze, tytuł omawianego obrazu - Cold Pastoral, czyli „,chłodna idylla”, albo też „zimna sielanka”, jest cytatem z ostatniej strofy poematu Johna Keatsa pt. Ode to a Grecian Urn (Oda do greckiej urny). ${ }^{25} \mathrm{~W}$ utworze tym Keats odnosi się do wieczności zapisanej w „,cichej formie" (silent form) kamienia - jak mówi malarz, komentując swe dzieło - do

${ }^{23}$ Burke's notion of „, beautiful” and „sublime” functions as a thesis of smoothness, gentle curves, and delicacy of nature, and as antithesis of terror, solitude and vastness of nature, both of which are rooted in the real world, rather than in a Hegelian Ideal. Price and Gilpin provide a synthesis with their formulation of the "picturesque”, which is on close examination related rather to chance and change in the maerial order of nature.

R. Smithson, Frederick Law Olmsted and the Dialectical Landscape, [w:] idem, The Collected Writings, (ed.) J. Flam, Berkeley - Los Angeles - London 1996, s. 159.

${ }^{24}$ Paul Collinson o kontrastach znamionujących obraz: The advertising boarding presents contradictions; ,"all” citizens should have responsibilities towards the empty cardboard and tarpaulin „doss” whilst the clever automobile marketing image makes use of Kylie Minogue to implicate us all in silencing any discord on the matter. The „doss”, the temporary architecture of the homeless, makes an aesthetic nod towards Robert Smithson's Partially Buried Shed at Kent State University 1970 (...) but towards differing ends."

Fragment korespondencji zamieszczony dzięki uprzejmości Artysty.

${ }^{25}$ Podaję niżej fragment utworu pt. Ode to a Grecian Urn Johna Keatsa oraz tę samą strofę w bardzo zgrabnym przekładzie Agnieszki Fulińskiej:

O Attic shape! Fair attitude! with brede

Of marble men and maidens overwrought,

With forest branches and the trodden weed;

Thou, silent form, dost tease us out of thought

As doth eternity: Cold Pastoral!

When old age shall this generation waste,

Thou shalt remain, in midst of other woe

Than ours, a friend to man, to whom thou say'st,

„Beauty is truth, truth beauty" - that is all

Ye know on earth, and all ye need to know.

http://www.poetryfoundation.org/poem/173742 [dostęp: 08.03.15] [ podkr. M. S.] 
urny jako „milczącego testamentu i świadka i zmienności ludzkiej natury” (mute testament and witness to humanity's transient nature). Powstaje zatem pytanie: Co przetrwa w pamięci świata po naszym stuleciu?

Przemijanie i płynność granic naszego (obrazu) świata stanowi także główny temat płótna opatrzonego tytułem Et in Arcadia lego, jak już wspomniałam biorącego udział w ostatniej edycji konkursu im. Johna Moores'a. Brzmienie tytułu stanowi oczywistą aluzję do „malowniczej elegii Poussina”, intrygującą zaś metaforykę obrazu najlepiej wyjaśnia sam Collinson: „Dwie skamieniałe figury, w tym jedna najwidoczniej trawiona przez trąd - niszczące skutki czasu - kontemplują dzieło niewidzialnego artysty. Stylizowana trupia czaszka jest nowoczesną wersją memento mori; EGO - czyli »jestem « zmienia się teraz w LEGO - »czytam«. Arkadyjski grobowiec jest teraz przedmiotem aktywnego odczytywania i wprowadza szerszy kontekst obecności - kontekst zrozumienia i interpretacji. Uzbrojony pojazd umieszczony na nagrobnej płycie stanowi odniesienie do pracy Hamiltona Finlay'a wyobrażającej opancerzony pojazd (panzer) w Arkadii. [Zob. Hamilton Finlay we współpracy z Georgem Oliverem, Arcadia, 1973, kolekcja Tate Gallery]. Mój czołg zdaje się bronić Arkadię przed jej wyprzedażą (...). Możliwość śmierci - grób i czaszka - skojarzona została z potencjalną utratą Arkadii, zmieniając się $\mathrm{w} »$ wizję raju utraconego « i ewokując niewyraźne (nieokreślone) »uczucie miękkiej, elegijnej nostalgii «"26.

Attycka formo! Piękna ideale

Wpisany w taniec kamiennych postaci,

Zdobny wiciami zdeptanymi w szale,

Ksztatcie milczacy, myśl się w tobie traci

Jako w wieczności: Te chłodne idylle!

Chodź z wieku tego nie zostanie człowiek,

Ty przetrwasz dumna w przyszłości udręce,

Nowym przyjazna ludziom, którym powiesz:

„Piękno jest prawdą, prawda pięknem”- tyle

Wiedzieć wam dane i nie trzeba więcej. (tłum. A. Fulińska)

http://antiquitates.blox.pl/resource/Keats_Oda.pdf [dostęp: 08.03.15] [ podkr. M. S.]

${ }^{26} \mathrm{Et}$ in Arcadia lego (...) makes use of Poussin's picturesque elegy. Two figures turned to stone, one apparently in a leprous condition - the ravages of time - contemplate the work of the unseen artist. The stylised death's head is a modern take on the usual memento mori; EGO - the "I am” is now LEGO - „I read”. The tomb in Arcady is actively read and is a broader contextual presence, one of understanding and interpretation. The armoured vehicle atop the plinth/tomb is a reworking of Ian Hamilton Finlay's work on the subject of the panzer in Arcady. My tank appears to fend off the sale of Arcadia (...). The possibility of death - the tomb and death's head-is allied to the potential loss of Arcadia and turned into „, a vision of a paradise lost” invoking a blurred ,feeling of soft, elegiac nostalgia”. Cytat z e-mailowej korespondencji; zamieszczony dzięki uprzejmości Artysty. 
Miniaturowe światy Collinsona - co prawda przetransponowane na dużych rozmiarów podobrazia, zachowujące jednak strukturę maleńkich „wysepek” i charakter ,antykwarycznych” wizji - przywodzić mogą również na myśl Baudrillardowską metaforę współczesnego społeczeństwa jako więzienia, i odwrotnie - instytucji karceralnej będącej społeczeństwem skondensowanym, sprowadzonym do stosownie małej skali (Czyż nawet Arkadia nie może być więzieniem, jeśli i do niej zakrada się śmierć i zniszczenie?). W takim duchu pisał francuski filozof, analizując sposób funkcjonowania parków rozrywki, takich jak na przykład Disneyland. Otóż, zdaniem Baudrillarda stanowić miałby on „,doskonały model wszystkich splatających się ze sobą porządków symulacji. „Tym, co przyciąga tłumy - konstatuje uczony - jest społeczny mikrokosmos, religijna, zminiaturyzowana rozkosz obcowania z rzeczywistą Ameryką, z jej wadami i radościami”27. Per analogiam, mikroświaty dioram Collinsona, eksplodujące w makroskalach znakomicie opracowanych płócien, przynoszą możliwość obcowania z rzeczywistością współczesnych ideologii, tutaj skompresowanych i skondensowanych, ze wspólnotą projekcji i lęków - omnes cives.

„Oto fantazja mikroskopu: fantazja życia w życiu albo też znaczenia nieskończenie zwielokrotnionego w obszarze samego znaczenia" - stwierdza Susan Stewart na stronach publikacji poświęconej nostalgii miniatur, a opatrzonej tytułem On Longing. Narratives of the Miniature, the Gigantic, the Souvenir, the Collection $^{28}$. Eksplorując ,sekretny żywot rzeczy” (obszerny passus zatytułowany The Secret Life of Things), amerykańska filolożka i poetka zauważa, że wszelkie światy złożone z maleńkich przedmiotów, ex definitione kulturowo znaczące (wszak miniatury nie istnieją w naturze), funkcjonują jako „modele porzadku, proporcji i równowagi" (,as a model of order, proportion and balance"). ${ }^{29}$ Jak powiada uczona: „Miniatura, wyrastająca z nostalgicznych wersji dzieciństwa i historii, reprezentuje lilipucią, a co za tym idzie - łatwo podlegającą manipulacji wersję ludzkiego doświadczenia, wersję oswojona i niepodatną na kontaminację"30.

${ }^{27}$ J. Baudrillard, Symulakry i symulacja, tłum. Sławomir Królak, Wyd. Sic!, Warszawa 2005, s. 18. [podkr. J. B.]

W innym zaś miejscu Baudrillard przekonuje nas, że: „Disneyland istnieje po to, by zataić fakt, że »rzeczywisty« kraj, cała »rzeczywista« Ameryka jest Disneylandem (trochę podobnie jak więzienia, które istnieją po to, by ukryć to, że całe społeczeństwo w swej banalnej wszechobecności ma charakter karceralny." Ibid., s. 19. [podkr. J. B.]

${ }^{28}$ S. Stewart, On Longing. Narratives of the Miniature, the Gigantic, the Souvenir, the Collection, Duke University Press, Durham and London 1993, s. 54.

${ }^{29}$ Ibid., s. 68.

${ }^{30}$ The miniature, linked to nostalgic versions of childhood and history, presents a diminutive and thereby manipulable version of experience, a version which is domesticated and protected from contamination. Ibid., s. 69. [thum. M. S.] [podkr. M. S.] 
W tak „oswojonym”, przyjaznym świecie nie ma miejsca na żywioł przypadku i entropii, na kontaminację oznaczającą niebezpieczeństwo powstania tworów hybrydalnych. W moim odczuciu alternatywna rzeczywistość miniatury ma w sobie zwykle coś z utopii lub przynajmniej z przeciwległego porządku antyutopii. Zwykle, jakkolwiek nie zawsze. Malarskie imaginarium Paula Collinsona nie ma nic wspólnego z pozytywną utopią, ani też nawet z antyutopią ,laboratoryjnej: niejako rzeczywistości wyspy, jakże silnie wpisaną w tkankę brytyjskiej literatury, (dość wspomnieć o Podróżach Guliwera Jonathana Swifta, Wyspie doktora Moreau Herberta G. Wellsa, czy też Władcy much Williama Goldinga). Teatr wyobraźni malarza zamknięty i zastygły w scenach dioram jest dość mroczny, lecz przepełnia go bardziej postmodernistyczna rezygnacja i melancholia, niż trwoga.

\section{Postmodernistyczna melancholia}

Melancholia Simplex (2012) - taki tytuł nadał jednemu ze swoich płócien Ged Quinn, urodzony w 1963 roku w Liverpoolu, pobierający w swym czasie nauki m.in. na amsterdamskiej Rijksakademie i düsseldorfskiej Kunstakademie, obecnie reprezentowany głównie przez Stephen Friedman Gallery w Londynie. Quinn jest autorem cyklu fascynujących martwych natur, w których wątki wanitatywne i motywy kwiatowe zaczerpnięte z ikonografii XVI i XVII-wiecznego malarstwa mistrzów holenderskich, splatają się z elementami pop-kultury, takimi jak filmowe kadry, (np. Ghosts and Benedictions, Hegel's Happy End). Ponowoczesne rozczarowanie rzeczywistością i tęsknota za heroiczną przeszłością - także, jak się zdaje, bezpowrotnie minioną erą w świecie sztuki - zaznacza się jeszcze dobitniej w pejzażach malowanych przez Anglika na wielkich rozmiarów płótnach. Są to, jak już wspomniałam, epickie kompozycje, obfitujące w liczne odniesienia do metaporządków filozofii i literatury, w zacienione symbole i sensy.

W przywołanym obrazie centralnie umiejscowiona postać, której upozowanie przywodzi na myśl wyobrażenia św. Sebastiana - męczennika za wiarę, ubrana jest w szaty ozdobione motywami rodem z konstruktywistycznego malarstwa. Owa pozbawiona życia figura spoczywa na czymś w rodzaju postumentu złożonego z ostro ciosanych, syntetycznych w formie, białych bloków kamienia. Czyżbyśmy oglądali ruiny modernizmu? Tak, czy inaczej, jesteśmy świadkami upadku i zmierzchu. Dowód na to stanowi napis: gloss, czyli „blask” umieszczony na filakterii wyłaniającej się z pyska martwego zwierzęcia.

Pozornie niebiański, „elizejski” - czy też może: ,arkadyjski” - spokój znamionuje malarską wizję Quinna zatytułowaną In Heaven Everything is Fine z 2012 roku. Moim zdaniem, kluczowy a jednocześnie najsilniej zabarwiony politycznie element 
owej sceny stanowi porośnięta bluszczem gilotyna znajdująca się w przestrzeni ruin gotyckiej architektury, zaopatrzonej też w element współczesny - urynał przywodzący oczywiście na myśl słynny ready-made Marcela Duchampa. Gilotyna, nader klarowny symbol Wielkiej Rewolucji Francuskiej, skojarzona została tu zatem z ,ikoną” antysztuki, banalnym artefaktem. Czyżby ta straszliwa maszyneria śmierci kojarzyła się artyście z ostatecznym upadkiem sztuki? Czy jego zdaniem procesy demokratyzacji kultury stanowiące efekt działalności teoretyków o redukcjonistycznej orientacji i wąskim spojrzeniu zepchnęły artworld na złe tory, spowodowały - parafrazując słowa Abrahama Molesa - „zużywanie się dzieł pod spojrzeniami”? Choć sam artysta nie nazbyt często komentuje swe prace, taka interpretacja wydaje mi się całkiem uzasadniona.

Tytułem dygresji pozwolę sobie dodać, że ostatnio media podawały wzruszającą wiadomość o śmiertelnie chorej kobiecie, która dzięki wsparciu Ambulance Wish Foundation spełniła ostatnie, wielkie marzenie, jakim było obejrzenie obrazów Rembrandta w Rijksmuseum. Zastanawiam się, czy ktokolwiek mógłby w takiej sytuacji marzyć o podobnym, swoistym ,pożegnaniu się" z pracami Duchampa? ${ }^{31}$ Jeśli, zgodnie z zapewnieniami artysty - W niebie wszystko jest $w$ porzadku, to co naprawdę wypełniałoby niebiańską przestrzeń?

Wyraźne odniesienie do rewolucji francuskiej zaznaczone zostało w tytule wystawy urządzonej przez Quinna w londyńskiej Wilkinson Gallery, a komentowanej między innymi przez Michaela Bracewella na łamach „Frieze Magazine” w numerze z marca 2008 roku. Fraza użyta jako motto pokazu - My Great Unhappiness Gives Me a Right to Your Benevolence, (pol. „,moje wielkie nieszczęście, daje mi prawo do pańskiej życzliwości”), stanowi bezpośrednie thumaczenie z języka francuskiego - il suffit que je sois bien malheureuse pour avoir droit à votre bienveillance. Wyimek ów pochodzi z listu zamieszczonego na słynnym płótnie Jacquesa-Louisa Davida z 1793 roku, na którym artysta, zdecydowanie opowiadając się po stronie rewolucyjnej rzezi, wyobraził moment Śmierci Marata. (Zupełnie inaczej scenę tę wyobraża Paul Baudry w roku 1860, czyniąc heroinę nie z Marata, lecz z tytułowej Charlotte Corday.)

Domniemane słowa listu-petycji Charlotte Corday stanowią zatem, w kontekście wystawy Quinna, typowo postmodernistyczny, rzecz by można „szkatułkowy” zabieg, cytat z cytatu. Jak stwierdza Bracewell we wspomnianym artykule: „Zdanie to, tak kwieciste, że aż melodramatyczne w tonie, zawiera jednak w swym sednie mechanizm zwodniczo subtelnego moralnego kontraktu, w którym role zwycięzcy i ofiary są, jeśli nie odwrócone, to przynajmniej dwuznaczne". ${ }^{32}$

$31 \mathrm{http} / / / \mathrm{www} . o p e n c u l t u r e . c o m / 2015 / 03 /$ terminally-ill-patients-visit-rembrandt-paintings.html [dostęp: 08.03.15]

${ }^{32}$ Michael Bracewell na łamach „Frieze Magazine”, nr $113 \mathrm{z}$ marca $2008 \mathrm{r}$.: It is a statement of exuberant near melodrama but contains at its core the mechanism of a deceptively subtle moral 
Wreszcie, last but not least, bodaj najbardziej upolityczniony spośród obrazów Quinna - Flaschenpost czyli List w butelce (2011). Oto, chłopiec w czapce czelisty, przypominający jednak subtelnego efeba z płócien Caravaggia obejmuje ofiarnego Baranka - klarowny symbol chrystologiczny. W prawej dolnej części kompozycji namalował artysta zmurszałą tratwę zaopatrzoną w żagiel z wyblakłą mapą świata, dźwigającą dodatkowo brzemię sentymentalnych, neogotyckich ruin. Znajdziemy tam dosłowny cytat z Das Eismeer Caspara Davida Friedricha - zminiaturyzowaną wersję obrazu niemieckiego mistrza romantyzmu. Co najistotniejsze jednak, na pozornie białej fladze wywieszonej z tratwy, oznaczającej wszakże kapitulację, dostrzec można nikły zarys wyblakłego Union Jack, flagi niegdyś tak dumnie powiewającej nad wielkim Imperium. Nieistniejącym już Imperium.

\section{Okrucieństwo wiosny}

Ackroyd w swym znakomitym studium o Albionie przywołuje jeden z poematów powstałych w VIII wieku - The Ruin. Ten ,topograficzny” utwór, wedle słów uczonego ,sam stanowiący ruinę”, zapewne fragment większej całości:

„Opisuje antyczne miasto, w którym ściany dawno runęły na ziemię, dachy rozpadły się, a kolumny rozsypały w kamieniste pryzmy. Niegdyś znajdowały się tam majestatyczne domostwa i przestronne westybule, lecz minęly setki pokoleń pozostawiając po sobie jedynie ciszę i rozkład. Owe ruiny symbolizują enta geweorc - pracę Olbrzymów. Jest to pojęcie dobrze wpisane w obszar anglosaskiej poezji, stosowane zarówno w sakralnych, jak i w laickich kontekstach. Stanowi ono wyraz czci wobec dawnych mieszkańców wyspy, a zarazem hołd złożony kruchości istnienia jako takiej. Nie odzwierciedla w żaden sposób chełpliwości triumfujących najeźdźców; chodzi raczej o autentyczną, głęboką świadomość przemijania cywilizacji”33.

„Najokrutniejszy miesiąc to kwiecień" (April is the cruellest month) - stwierdza przywoływany na początku Eliot. Żyjemy prawdopodobnie w przededniu wielkiej

contract, in which the roles of victor and victim become, if not reversed, then at least ambiguous.

http://www.frieze.com/issue/review/ged_quinn/ [dostęp: 08.03.15] [tłum. M. S.]

${ }^{33}$ It describes an ancient city where now the walls have fallen, the roofs decayed and the pillars crumbled into heaps of stone. Once it contained bright halls and majestic houses, but a hundred generations have passed leaving only silence and decay. These ruins represent 'enta geweorc', the work of giants. It is a familiar phrase in Anglo-Saxon poetry appearing in both sacred and secular contexts; it is alike a tribute to the past inhabitants of this island and a homage to transience itself. It does not reflect any vainglory of the victorious invader but, rather, a genuine and sophisticated awareness of passing civilizations. Ackroyd, op. cit., s. 54-55. [tłum. M.S.] [podkr. P.A.] 
wiosny ludów, eksplozji nowych filozofii, intelektualnego exodusu, wreszcie - zmierzchu tyleż błogiego, ile złudnego poczucia kontroli. Fałszywego poczucia, że żyjemy wciąż w centrum znanego nam świata. Czy możemy być w nim czegokolwiek pewni?

Jak konstatuje Kitaj we wspomnianym już manifeście, jedynym miejscem, które zdaje się mniej oczywistym niż cały zewnętrzny świat, jest pracownia artysty. „, Wszyscy dobrzy malarze - powiada dalej - winni pozostać w swoich pokojach, Nietzsche definiuje sztukę (...) jako pragnienie bycia innym, pragnienie bycia gdzie indziej. Malarze są stadem wyróżniających się samotników" ${ }^{34}$. W studiach owych odmiennych samotników, tworzących rzeczy niemodne, powstają intelektualnie wysublimowane teksty, interesujące i niekiedy zapewne także - profetyczne traktaty o kulturze.

\section{SUMMARY}

The main subject of the present article is the metaphoric, iconographically complex and formally sophisticated landscapes by two contemporary English painters: Paul Collinson and Ged Quinn. The starting point of the discussion is the category of Englishness analyzed in its time by inter alia Nikolaus Pevsner. Most importantly, the pictures discussed in the study, which are outside of the mainstream of now fashionable solutions, can be interpreted as symptomatic of post-imperial culture tired of the orders of great ideologies. Both Collinson's hyperrealistic canvases reproducing the "microcosms" of intricately constructed diaporamas, and Quinn's pictures polished in the glazing technique, which contain subtle references to Jacob Ruisdael, Claude Lorrain, or Caspar David Friedrich, are in a sense political "texts" or even "manifestos". What can be discerned in them is the expression of strong Kulturpessimismus, the reflection of a more and more condensed mixture of disillusionment and anxiety in our culture.

${ }^{34}$ The only place which seems less uncertain than the wide world is the room in which the Diasporist tries out his pictures, whoch are about and decided by that Diasporic world outside his room (...) But all good painters must stay in their rooms. Nietzsche defines art, beautifully I think, as the desire to be different, the desire to be elsewhere. Painters are a herd of differing loners. R. B. Kitaj, First Diasporist Manifesto, Thames\&Hudson, New York 1989, s. 89-91. [tłum. M.S.] 
Pobrane z czasopisma Annales L - Artes http://artes.annales.umcs.pl

Data: 26/04/2023 14:49:40

\section{WYBÓR ILUSTRACJI}

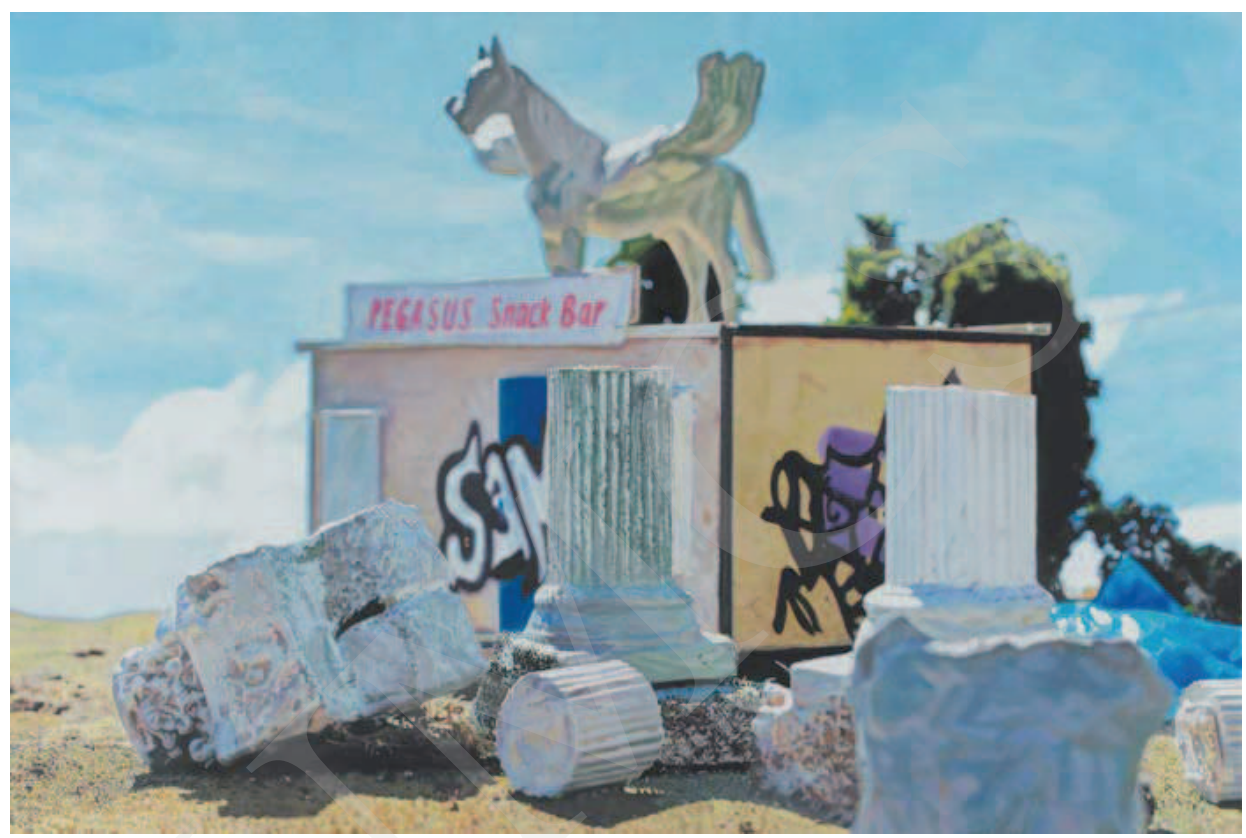

Ilustracja 1. Paul Collinson, The Temple of Ancient Virtue (Pegasus Snack Bar), olej na pótnie, $120 \times 180 \mathrm{~cm}, 2010$.

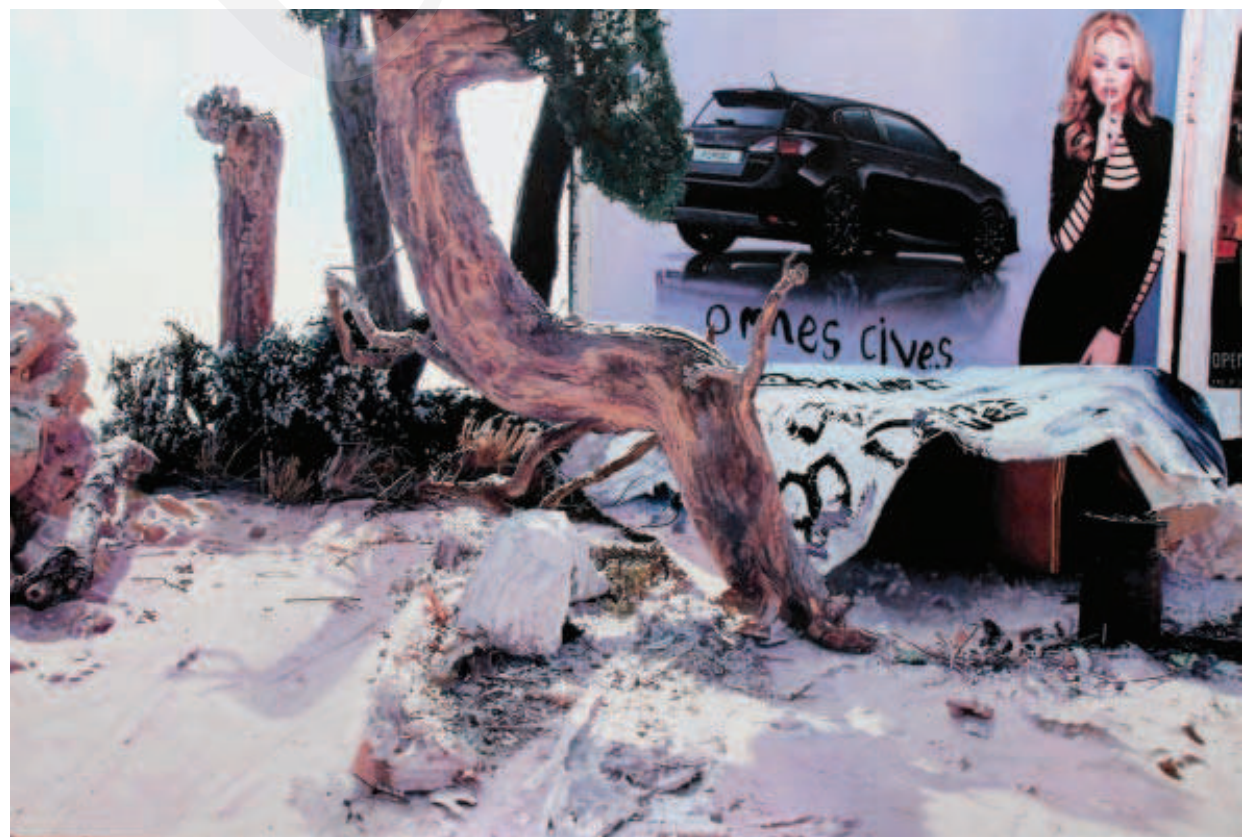

Ilustracja 2. Paul Collinson, Cold Pastoral, olej na pótnie, 120 x 180 cm, 2014. 
Pobrane z czasopisma Annales L - Artes http://artes.annales.umcs.pl

Data: 26/04/2023 14:49:40

$66 \quad$ Małgorzata Stępnik

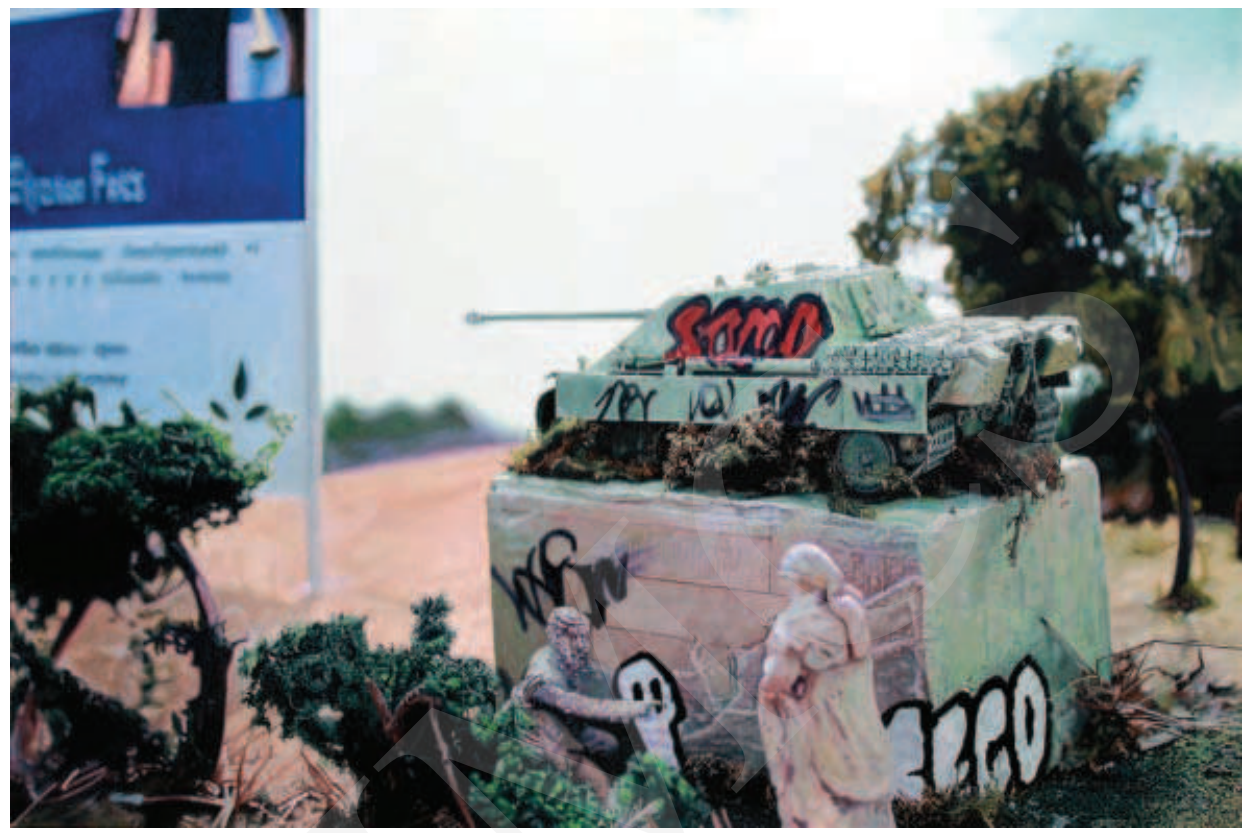

Ilustracja 3. Paul Collinson, Et in Arcadia lego, olej na pótnie, 120 x 180 cm, 2013.

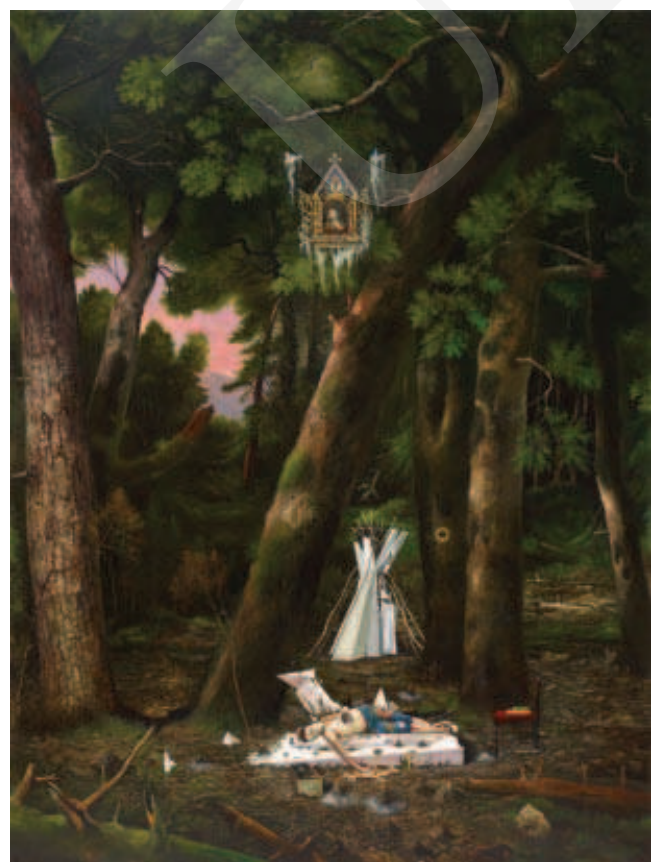

Ilustracja 4. Ged Quinn, Melancholia Simplex, olej na płótnie, 264,5 x 200 x 5 cm, 2012.

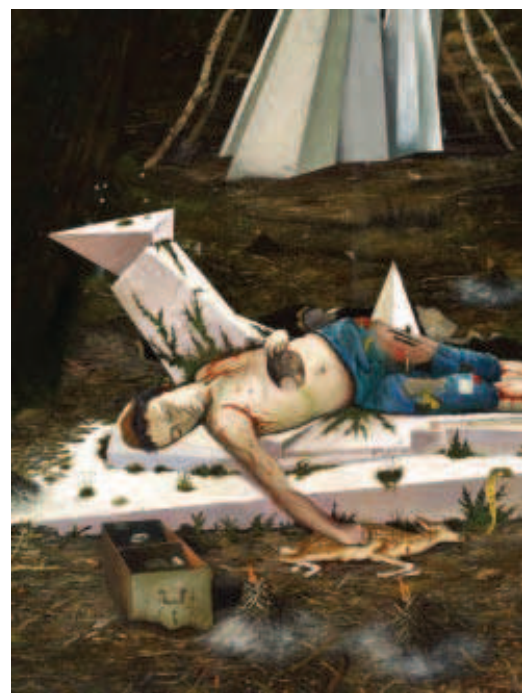

Ilustracja 5. Melancholia Simplex, detal. 
Pobrane z czasopisma Annales L - Artes http://artes.annales.umcs.pl

Data: 26/04/2023 14:49:40

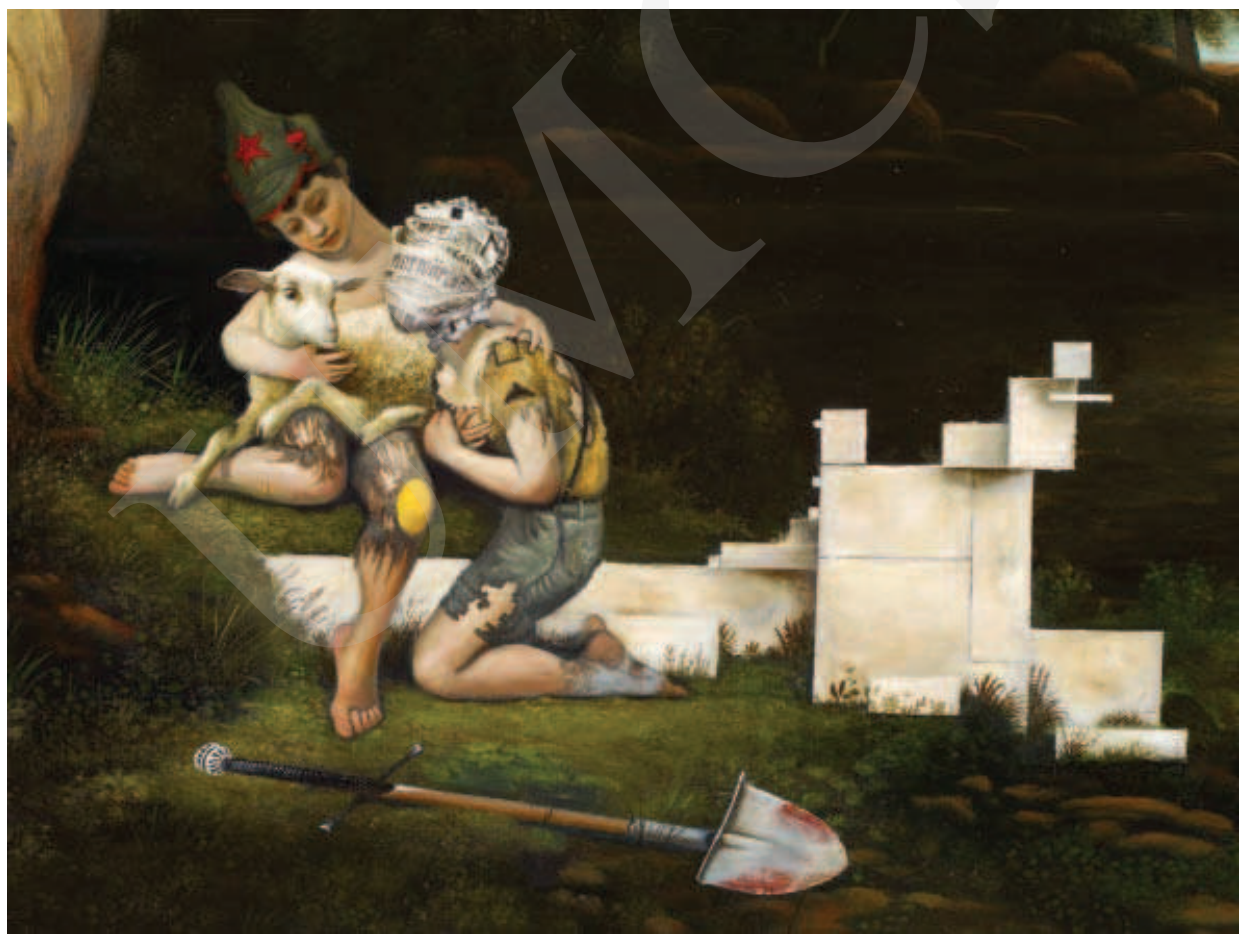

Ilustracja 6. Ged Quinn, Flaschenpost, olej na płótnie, 294,5 x 200 x 4,5cm, 2011. 